\title{
Investigation and Analysis of the Status Quo of the Practical Teaching Ability of English Normal Students in the Higher Vocational College in China
}

\author{
Zhen Zhou ${ }^{1}$ \\ ${ }^{1}$ Foreign Language School, Nanchang Normal University, Nanchang, Jiangxi, China \\ Correspondence: Zhen Zhou, Foreign Language School, Nanchang Normal University, Nanchang, Jiangxi, China. \\ E-mail: zoye100@sina.com
}

Received: August 14, 2017 Accepted: October 5, 2017 Online Published: October 8, 2017

doi: 10.5539/elt.v10n11p15 URL: http://doi.org/10.5539/elt.v10n11p15

\begin{abstract}
The teaching ability is the key factor to decide the quality of teaching. How to train and improve the teaching ability of teachers has become a widespread concern of experts and scholars in the field of education and linguistics. The research investigates the status of students' practical teaching ability in the higher vocational college, explores the problems and ways to improve the teaching skills of English normal students and try to provide a scientific basis and theoretical guidance for higher vocational colleges and universities through the questionnaire research of practical teaching ability of students of three vocational colleges in Jiangxi Province, using descriptive statistics.
\end{abstract}

Keywords: practical teaching ability, linguistic ability, research teaching, reflective teaching, microteaching

\section{Introduction}

The teaching ability is the important part of teachers' quality and it is the key factor to determine the quality of teaching and teaching art. And the research on teachers' teaching ability has become an important research direction in the field of education and linguistics (Shulman, 1986; Tsui, 2003; Dai, 2006; Guo, 2016; Wen, 2016; Yi, 2017; Meng, 2017). The current research on the teaching ability of teachers at home and abroad mainly focus on quality and culture (Gatbonton,1999; Shi, 2009), composition and connotation of teaching ability (Krashen, 1981; Zou, 2009), the development of foreign language teaching ability and its influencing factors (Lvyan, 2016; Jianyong, 2017), and teaching skills training (Li, 2010; Zhao, 2011), the training mode of teaching strategies and teaching skill (Wallace, 1993; Lu, 2017), assessment system (Sehmelkin, 1997; Lu, 2011) and so on. The main research objects are the university normal students and undergraduate students, and the study on the students' English teaching ability in higher vocational colleges is very few, most of which are qualitative research.

The research selected 800 English normal interns in three vocational colleges in Jiangxi province, carried out an empirical quantitative investigation on the teaching ability, which were investigated by questionnaires on the situation of teaching ability of English normal interns, explored the problems and ways to improve the teaching skills of English normal students to provide a scientific basis and theoretical guidance for higher vocational colleges.

\section{Research Program}

\subsection{Subjects of Study}

The subjects are 800 English normal interns of Grade 2015 from three universities, of which 240 students from Jiangxi Institute of Education, 290 students from Jiangxi Institute of Technology, and 270 students from Nanchang Teachers College. Of the 800 students, 740 are girls, and 60 are boys.

\subsection{Research Methods}

The research employs quantitative and qualitative researching methods, and obtains data through questionnaires, observation and interviews to understand the practical teaching ability of English normal interns. The questionnaire is adapted from Zhao's questionnaire on the teaching ability of English interns (2010). The questionnaire design adopts Likert five subscales method, 1, 2, 3, 4, 5, that is, very weak, weak, average, strong, very strong respectively. The questionnaire is tested by reliability, validity, and item analysis. 35 items are 
retained, and the reliability of the questionnaire is 0.9547 . The criteria for assessing students' practical ability in English teaching are that the mean is higher than 3.5 is good, the mean below 2.4 is low, and the mean between 2.5 and 3.4 is of an average level. A total of 850 questionnaires are issued, and 800 valid questionnaires are retrieved, with an effective rate of $94 \%$. After the questionnaire data were collected, SPSS18.0 software was used for the statistical analysis.

\section{Research Findings and Discussions}

\subsection{Comprehensive Analysis of Teaching Ability}

The statistical analysis of this survey on the higher vocational English normal interns' teaching ability shows that (Table 1), the five teaching ability level (linguistic ability, creative teaching ability, teaching assessment ability, teaching design ability and classroom teaching implementation ability) is generally low (mean less than 3 ), the deviation is small and the students teaching level is similar (standard deviation less than 0.9). The five teaching abilities of the surveyed students are sorted from strong to weak: classroom teaching implementation ability, teaching design ability, teaching assessment ability, creative teaching ability and linguistic ability.

Table 1. The descriptive statistics of teaching abilities $(\mathrm{N}=800)$

\begin{tabular}{llll}
\hline Item & Mean & SD & Rank \\
\hline Linguistic ability & 2.3674 & .8822 & 5 \\
Creative teaching ability & 2.5918 & .6453 & 4 \\
Teaching assessment ability & 2.8190 & .8081 & 3 \\
Teaching design ability & 2.9320 & .8167 & 2 \\
Classroom teaching implementation ability & 2.9901 & .8290 & 1 \\
\hline
\end{tabular}

Usually, English normal interns have teaching practice in the course of English teaching methods, and many students also have some teaching practice experience during the summer and winter holidays. Furthermore, in the decades of study, students are familiar with the teacher's teaching work. Therefore, students' classroom teaching implementation ability, teaching design ability and teaching assessment ability are relatively strong. The survey also shows that English normal interns' ability of creative teaching is weak, the deviation is very small, and students generally lack the ability of creativbe teaching, so we need to vigorously promote the innovative spirit of students. To cultivate students' innovative spirit, the teacher should have the abilities at first. In addition, the investigation demonstrates that the students' linguistic ability is in the last in all teaching abilities. It is well known that the linguistic ability should be the most basic quality that English teachers should have. However, the students' linguistic ability is very low, and their basic skill of language is very weak. Therefore, teachers, educators and experts should pay more attention to this problem.

\subsection{Analysis of Linguistic Ability}

In the English classroom, teaching discourse is an important index to measure the language level of language teachers. Teacher's language is the most direct and convenient language source for students to imitate, and teachers' language level has a direct impact on students' English learning.

The teacher's linguistic ability includes English communicative ability, English interpretation ability, English using ability and English writing ability (Zhao, 2010). The survey shows that among the four sub skills, students have the strongest English writing ability, followed by English using ability and English interpretation ability, while English communicative competence is the weakest (Table 2). This is closely related to the traditional teaching method which Chinese English teachers often use in the test-oriented education for quite a long time. In China's English education, the grammar writing is over-stressed and the communication ability is ignored, so students' writing skills is relatively better in comparison with other linguistic abilities. 
Table 2. The descriptive statistics of linguistic ability $(\mathrm{N}=800)$

\begin{tabular}{lllllllll}
\hline Item & Mean & SD & Rank & 1 & 2 & 3 & 4 & 5 \\
\hline English communicative ability & 2.1728 & .9688 & 4 & $22 \%$ & $46 \%$ & $27 \%$ & $5 \%$ & 0 \\
English interpretation ability & 2.3120 & .8673 & 3 & $19 \%$ & $33 \%$ & $40 \%$ & $8 \%$ & 0 \\
English using ability & 2.3890 & .8639 & 2 & $25 \%$ & $24 \%$ & $43 \%$ & $7 \%$ & $1 \%$ \\
English writing ability & 2.6485 & .8236 & 1 & $12 \%$ & $21 \%$ & $56 \%$ & $11 \%$ & 0
\end{tabular}

Although on the whole, the English writing ability is the strongest among the students' linguistic ability, yet the survey shows that students with strong writing ability are just a few (only $11 \%$ ), there are $56 \%$ students who think their writing ability is average. The results reflect the status of students, that is, their general level is not so good. Because writing is a comprehensive reflection of vocabulary, semantics, syntax, grammar, thinking and so on. In addition, although the design concept of the new curriculum is based on the principle of communication, the overall goal is to cultivate students' comprehensive ability of using the language, yet the students' communicative competence in English is the lowest level in the survey of linguistic ability. An important reason for this situation is that the students' time investment is not enough, they do not work hard enough. The investigation indicates that $66 \%$ of the students only spends $0-1$ hour on the practice of English listening and speaking, while $4 \%$ of the students do not take time to practice at all. In a word, higher vocational normal students' English linguistic ability is low, so it is urgent to improve their English linguistic ability.

\subsection{Analysis of Creative Teaching Ability}

The investigation shows that students' teaching reflective ability, listening and speaking skills are in the top two in the aspect of creative teaching ability, and students are more familiar and more adept in these two abilities. But the mean of teaching activities creating and language writing ability is low, and students' creative ability is poor (Table 3). China's long-term "spoon feeding" education model has led to widespread lack of creativity among students. The mean of statistical analysis, teaching research, paper writing, topic teaching and research and teaching research are all less than 2.6, indicating that students' scientific research ability is very weak. The survey shows that $84 \%$ of students think that they should have certain scientific research ability, most students know that the teacher should not only impart knowledge, but also should be a researcher. However, due to the absence of teaching and research related courses in higher vocational normal colleges, and students are not required to write theses either, they have almost never been exposed to any scientific research. Therefore, their scientific research ability is weak.

Table 3. The descriptive statistics of creative teaching ability

\begin{tabular}{lllllllll}
\hline Item & Mean & SD & Rank & 1 & 2 & 3 & 4 & 5 \\
\hline Topic teaching and research & 2.3400 & .7857 & 9 & $16 \%$ & $41 \%$ & $38 \%$ & $5 \%$ & 0 \\
Project applying & 2.3500 & .8213 & 8 & $15 \%$ & $40 \%$ & $41 \%$ & $3 \%$ & $1 \%$ \\
Paper writing & 2.3800 & .7901 & 7 & $14 \%$ & $40 \%$ & $40 \%$ & $6 \%$ & 0 \\
Teaching research & 2.4500 & .8329 & 6 & $14 \%$ & $37 \%$ & $41 \%$ & $8 \%$ & 0 \\
Statistical analysis & 2.5700 & .8521 & 5 & $10 \%$ & $37 \%$ & $38 \%$ & $15 \%$ & 0 \\
Language creating & 2.5800 & .7576 & 4 & $9 \%$ & $35 \%$ & $48 \%$ & $8 \%$ & 0 \\
Teaching activities creating & 2.6500 & .8613 & 3 & $9 \%$ & $29 \%$ & $50 \%$ & $10 \%$ & $2 \%$ \\
Lesson assessing & 2.8000 & .7238 & 2 & $5 \%$ & $24 \%$ & $55 \%$ & $14 \%$ & 0 \\
Teaching reflection & 2.9200 & .7453 & 1 & $6 \%$ & $16 \%$ & $60 \%$ & $17 \%$ & $1 \%$ \\
\hline
\end{tabular}

\subsection{Analysis of Teaching Assessment Ability}

The teaching assessment ability is an essential ability for English teachers and it is an important component of the course system of English teaching. In terms of teaching assessment ability, the mean of the three abilities is less than 3, all are weak (Table 4). Specifically, assessment of their teaching ability ranks first, $19 \%$ of the students think that this ability is strong, $2 \%$ very strong, $50 \%$ general, students can evaluate their teaching effect; 
the mean of discipline examination ability is slightly low, $54 \%$ of students think that their own ability is average, only $16 \%$ strong, $2 \%$ strong selection. The ability to predict teaching effect is the weakest, only $14 \%$ students have a strong choice, and $1 \%$ student choose "very strong".

Table 4. The descriptive statistics of teaching assessment ability $(\mathrm{N}=800)$

\begin{tabular}{llllllllll}
\hline Item & Mean & $\mathrm{SD}$ & $\mathrm{N}$ & Rank & 1 & 2 & 3 & 4 & 5 \\
\hline The ability to predict teaching effect & 2.7200 & .7768 & 800 & 3 & $5 \%$ & $31 \%$ & $49 \%$ & $14 \%$ & $1 \%$ \\
Testing and assessing ability & 2.8400 & .8357 & 800 & 2 & $8 \%$ & $21 \%$ & $54 \%$ & $15 \%$ & $2 \%$ \\
Assessing self-teaching ability & 2.8900 & 092 & 800 & 1 & $3 \%$ & $26 \%$ & $50 \%$ & $9 \%$ & $2 \%$ \\
\hline
\end{tabular}

\subsection{Analysis of Teaching Design Ability}

The teaching design means that before the classroom teaching, the teacher is clear about the learning course, teaching objectives, teaching content, teaching focus, teaching tasks and teaching methods, and can also predict the problems and possible teaching effect in the teaching so as to achieve the expected teaching effect. The teacher is the chief designer of the classroom teaching, and the teaching design level is a very important basic skill of the teacher.

The survey result of the five sub skills of teaching design ability shows that (Table 5), students' cognitive ability is the strongest, the students can understand the general learning situation, have the awareness of individualized teaching; The ability to set teaching objective ranks second, and the distribution is discrete, the students are in the different levels in this ability; The third is the ability to use textbooks and choosing teaching methods is the weakest. Because the students lack real practical teaching experience, they do not know how to deal with the teaching objective and the teaching materials, teaching design ability is weak, so usually they used the teaching method the teacher used before, and they are not good at choosing a flexible teaching method.

Table 5. The descriptive statistics of teaching designing ability $(\mathrm{N}=800)$

\begin{tabular}{lllllllll}
\hline Item & Mean & SD & Rank & 1 & 2 & 3 & 4 & 5 \\
\hline Choosing teaching methods & 2.8200 & .7789 & 5 & $4 \%$ & $26 \%$ & $51 \%$ & $17 \%$ & 0 \\
Designing teaching plan & 2.8800 & .7635 & 4 & $4 \%$ & $22 \%$ & $57 \%$ & $18 \%$ & $1 \%$ \\
Using the textbook & 2.9100 & .8016 & 3 & $5 \%$ & $23 \%$ & $51 \%$ & $20 \%$ & $1 \%$ \\
Setting teaching objective & 2.9400 & .8878 & 2 & $8 \%$ & $20 \%$ & $47 \%$ & $23 \%$ & $2 \%$ \\
Knowing about students & 3.1300 & .8379 & 1 & $5 \%$ & $16 \%$ & $50 \%$ & $27 \%$ & $2 \%$ \\
\hline
\end{tabular}

\subsection{Analysis of Classroom Teaching Implementation Ability}

The ability to implement classroom teaching is a factor that the teachers use to promote students' learning in classroom decision-making. Among the top five are ability of homework arrangement and correction, ability to help learners with learning difficulties, ability to use modern technology, ability to ask questions and to arouse students' enthusiasm for learning.

The survey on sub skills of the ability to implement the classroom teaching indicates that (Table 6) students are stronger in the abilities as follows, homework assignment and correcting ability, learning ability, the ability to help the students with learning difficulty, the ability to use modern technology, inquiry ability, the ability to arouse the enthusiasm of students' learning, the error correction ability, classroom organization and management ability. Because over the ten years of study the students are familiar with the teacher's classroom teaching, they will learn some subtle methods of classroom teaching consciously or unconsciously. And the abilities such as brief strokes, black board writing, creating language environment, recognizing and using language practice opportunities and ability to answer and feedback are relatively weak. Because these five skills are very demanding, students are required to have a solid foundation, and also need innovation. In these five items, the mean of the brief stroke teaching ability is the lowest and the deviation is the highest. The reason may be that the teachers and students in the scientific and technological age ignore the role of the brief stroke teaching. But because brief strokes are vivid and simple, it plays an indispensable role in elementary and middle school, and it 
is the basic skill that students should have. Normal students should strengthen their brief stroke capability in order to improve their teaching ability.

Table 6. The descriptive statistics of classroom teaching implementation ability

\begin{tabular}{lllllllll}
\hline Item & Mean & SD & Rank & 1 & 2 & 3 & 4 & 5 \\
\hline Brief strokes & 2.4600 & 1.0095 & 12 & $20 \%$ & $30 \%$ & $37 \%$ & $10 \%$ & $3 \%$ \\
Blackboard writing & 2.7800 & .8657 & 11 & $7 \%$ & $25 \%$ & $50 \%$ & $15 \%$ & $3 \%$ \\
Creating language situation & 2.7900 & .8158 & 10 & $5 \%$ & $32 \%$ & $46 \%$ & $16 \%$ & $1 \%$ \\
Recognizing and using language opportunities & 2.8000 & .7903 & 9 & $4 \%$ & $30 \%$ & $50 \%$ & $15 \%$ & $1 \%$ \\
Answering and feedback & 2.8200 & .7104 & 8 & $3 \%$ & $25 \%$ & $56 \%$ & $16 \%$ & 0 \\
Classroom organizing and management & 2.8400 & .8018 & 7 & $5 \%$ & $28 \%$ & $48 \%$ & $18 \%$ & $1 \%$ \\
Error correcting & 2.8800 & .8157 & 6 & $5 \%$ & $23 \%$ & $52 \%$ & $18 \%$ & $2 \%$ \\
Activating students & 2.9400 & .8213 & 5 & $1 \%$ & $30 \%$ & $44 \%$ & $21 \%$ & $4 \%$ \\
Questioning & 2.9500 & .7957 & 4 & $5 \%$ & $22 \%$ & $48 \%$ & $25 \%$ & 0 \\
Using modern technology & 2.9600 & .8313 & 3 & $3 \%$ & $21 \%$ & $52 \%$ & $21 \%$ & $3 \%$ \\
Helping academic backward students & 2.9800 & .8265 & 2 & $3 \%$ & $23 \%$ & $51 \%$ & $20 \%$ & $3 \%$ \\
Task assigning and correcting & 3.0200 & .8278 & 1 & $5 \%$ & $15 \%$ & $55 \%$ & $22 \%$ & $3 \%$ \\
\hline
\end{tabular}

\section{Suggestions for Improving Students' Practical Teaching Ability}

The following suggestions are put forward to improve the students' practical teaching ability in view of the relatively weak ability and existing problems of the students' practical teaching ability according to the above investigation and analysis results.

\subsection{To improve Students' Learning Quality through Reforming the Curriculum and Refining Curriculum Teaching Method}

The survey results show that students' linguistic ability is the weakest in the five teaching abilities. The linguistic ability is the foundation of other abilities, and there are no other abilities without linguistic ability. In order to improve students' linguistic ability effectively, the current curriculum arrangement must be reformed. Colleges should increase the teaching time of intensive reading, grammar, listening, oral English, and film appreciation, and teachers should teach in English, which is essential for students to improve their English ability. Higher vocational normal students are weak in foundation and self-control, and teachers should strictly request and supervise students closely so as to improve their language proficiency. For English normal students in the higher vocational college, in addition to the curriculum of brief strokes, head teacher course, calligraphy, pedagogy, educational psychology and teaching methods and so on, we should strengthen the "three characters, one painting" ( "three characters" refers to chalk writinf, pen writing and brush writing.) course and student training, and offer some elective teaching courses, such as introduction of the second language acquisition theory and English teaching plan writing, English testing, English curriculum design, interpretation of curriculum teaching, statistical methods to refine the teaching curriculum, and improve students' teaching ability.

\subsection{To Improve the Creative Teaching and Assessment Ability of Students through Research Teaching and Reflective Teaching}

To advocate research-based teaching, we must first change the role of the teacher, the classroom is no longer dominated by the teacher. The teacher should be a mentor, facilitator, and scaffold to help students to learn. The classroom atmosphere should be harmonious and democratic, and the classroom teaching activities should be student-centered and enable students to actively participate in the inquiry and develop their innovative thinking in the process of participation, experience, thinking, and cooperation. The reflective teaching is equally important, and the core of teacher development is reflection. After each practice course and lecture, students should reflect, and also turn teaching reflection into action, only in this way will their teaching level be improved. The higher vocational colleges do not set up scientific research courses, and there is no graduation thesis writing requirements on students, which is not good for students' future teaching and scientific research. Thus in order to improve the students' scientific research ability, first of all, the college should offer courses related to teaching 
research, and make students have a preliminary understanding of scientific research methods.

\subsection{To Conduct Case Discussion and Analysis to Improve Classroom Design Ability}

The method of case teaching is to guide students to discuss and analyze the special situation by describing a specific teaching situation with problems. Teachers can choose some famous classic, inspiring innovation or the simulation case or the real case of students, make the students watch the video through the case or the idea of special situations, get the students to cooperate to discuss and analyze. In the case study method, teachers should train students to observe, analyze, sum up and innovate their thinking ability. The teacher should guide students to look into the case carefully, to have a careful analysis of the subtle beauty of classroom teaching design in the case and find out some places that shall be improved, and summarize the lessons in the case and inspire students' critical thinking, and make students actively design classroom teaching. The case teaching method has broken the traditional teaching of the unified, broad, rigid teaching mode. Because the teaching method is more targeted, practical, instructive and inquiry, it is more suitable for teaching, and more conducive to improving students' classroom teaching design ability.

\subsection{To Improve Classroom Teaching Implementation Ability through Microteaching and Practice}

The micro teaching is a new method to train normal students or teachers in classroom teaching skills based on modern educational theory and modern audio-visual equipment. Microteaching classroom is small scale. A general training group only comprises 5 to 8 people, and a fragment of skill training lasts for 5-10 minutes. Because of its rapid, real feedback, normal university students can effectively improve the students' teaching skills through the micro teaching and discuss learning. The micro teaching is only simulated teaching, in which teachers should also organize students to go to primary and secondary schools to observe the teacher classroom, carry out seminars, and invite excellent primary and secondary school teachers to give lectures. Teaching internship is an important part of teacher training, but the average practice time is only four weeks or a semester at most, while the teaching practice in foreign countries is longer, for example, the practice time in Germany is 18 months. The quality of teaching practice is directly related to the practice time. Furthermore, the teaching environment requires "cooperation", namely, college teachers should go to middle or primary schools to conduct "practice interaction", primary and middle school teachers should participate in university classroom and offer their guidance and suggestions, and the colleges should cooperate with practice base to conduct cooperative innovation.

\section{Conclusion}

It is a common phenomenon that vocational college normal students are weak in teaching ability. In order to improve the practical ability of students and improve the quality of vocational college education, we should reform the curriculum, strengthen the teaching method, refine the basic curriculum, advocate research teaching, reflective teaching, and strive to improve the educational innovation and education assessment ability of teachers and students. Besides, we can improve students' ability to design classroom teaching, pay more attention to teaching practice, improve the capability of classroom teaching implementation through micro teaching, and practice. Through these ways the teaching ability of higher vocational normal college students' can be improved to some extent.

\section{References}

Cai, L. Y. (2016). The Enlightenment of service learning to practice teaching of higher vocational English education. Journal of Shaoguan University, 1, 169-173.

Dai, W. D, \& Ren, W. (2006). Foreign language teaching and teacher development: theory and practice. Shanghai: Shanghai Foreign Language Education Press.

Guo, M. H. (2016). Looking at the practical teaching ability of English majors in the perspective of college entrance examination reform. Education, 7, 256-258.

Gatbonton, E. (1999). Investigating experienced ESL teachers' pedagogical knowledge. Modern Language Journal, 83, 35-50. https://doi.org/10.1111/0026-7902.00004

Li, L. (2010). Current situation and Countermeasures of teaching skill training for normal college students. China Adult Education, 8, 81-82.

Lu, L. J. (2011). The research on the assessment system of teaching skills of normal university students-based on the study of education internship in the Central China Normal University, Central China Normal University master thesis.

$\mathrm{Lu}, \mathrm{Z}$. (2017). Investigation and analysis of maintaining of the teaching ability of English teachers in local 
universities. Forum on Higher Education, 6, 73-76.

Meng, Q. L. (2017). A multi dimensional approach to foster the practical teaching ability of college English normal students--taking Shaoguan University as an example. Journal of Shaoguan University, 5, 53-56.

Sehmelkin, L. P. (1997). Faculty perspectives on course: teacher assessment. Research in Higher Education, 38, 575. https://doi.org/10.1023/A:1024996413417

Shi, G. S., \& Zhou, Y. (2009). The investigation of excellent English teachers' quality of older generation. Foreign language Teaching and Research, 2, 26-29.

Shulman, L. (1986). Those who understand: knowledge growth in teaching. Educational Researcher, 2, 55-59. https://doi.org/10.3102/0013189X015002004

Song. J. Y. (2017). Construction of the training model of critical thinking ability in college English teaching. Journal of Wuhan Institute of Metallurgy Administrators, 2, 71-73.

Tsui, A. B. M. (2003). Understanding Expertise in Teaching: Case Studies of Second Language Teachers. Cambridge: CUP. https://doi.org/10.1017/CBO9781139524698

Wallace, M. (1993). Training Foreign Language Teachers: A Reflective Approach, Cambridge: Cambridge University Press.

Wen, Q.H. (2016). Research on the teaching ability of English majors. English Teachers, 16, 32-36.

Yi, C. Y., \& Shan, H. (2017). Research on the integration of basic English course into the teaching skills training of English normal students in the border area. Western Quality Education, 1, 66-67.

Zhao, F. Y. (2010). Research on the development of discipline teaching ability of English normal students. Doctoral dissertation of Shanghai International Studies University.

Zhao, W. H. (2011). Current situation and Countermeasures of teachers' vocational skills training in normal universities. Education and Profession, 12, 63-64.

Zou, W. C. (2009). Study on pre service education of foreign language teachers in China's basic education. Foreign Language Teaching Theory and Practice, 1, 1-16.

\section{Copyrights}

Copyright for this article is retained by the author(s), with first publication rights granted to the journal.

This is an open-access article distributed under the terms and conditions of the Creative Commons Attribution license (http://creativecommons.org/licenses/by/4.0/). 